\title{
Morphometric Sex Determination of North American Golden Eagles
}

\author{
Author(s): Al HarmataGeorge Montopoli
}

Source: Journal of Raptor Research, 47(2):108-116.

Published By: The Raptor Research Foundation

https://doi.org/10.3356/JRR-12-28.1

URL: http://www.bioone.org/doi/full/10.3356/JRR-12-28.1

BioOne (www.bioone.org) is a nonprofit, online aggregation of core research in the biological, ecological, and environmental sciences. BioOne provides a sustainable online platform for over 170 journals and books published by nonprofit societies, associations, museums, institutions, and presses.

Your use of this PDF, the BioOne Web site, and all posted and associated content indicates your acceptance of BioOne's Terms of Use, available at www.bioone.org/ page/terms_of_use.

Usage of BioOne content is strictly limited to personal, educational, and noncommercial use. Commercial inquiries or rights and permissions requests should be directed to the individual publisher as copyright holder. 


\title{
MORPHOMETRIC SEX DETERMINATION OF NORTH AMERICAN GOLDEN EAGLES
}

\author{
Al HARMATA ${ }^{1}$ \\ Ecology Department, Montana State University, Bozeman, MT 59717 U.S.A. \\ GeORGE MonTOPOLI \\ Department of Mathematics, Arizona Western College, Yuma, AZ 75986 U.S.A.
}

\begin{abstract}
We made up to 12 measurements of 79 captured Golden Eagles (Aquila chrysaetos canadensis) to evaluate best metrics for noninvasive, morphometric determination of sex. Sex of 43 male and 36 female Golden Eagles was confirmed post-release: 60 by DNA analysis and 19 by position during copulation. Eagles in adult plumage made up $57 \%$ of eagles of confirmed sex. All male and female morphometric means differed $(P<0.01)$ but most $(n=10)$ metric ranges overlapped $>10 \%$ between sexes. There was no overlap between sexes for the hallux claw (HAL) and head length (HEAD) metrics, regardless of age class. All male HAL and HEAD measurements were $\leq 51.7 \mathrm{~mm}$ and $119.5 \mathrm{~mm}$, respectively. All female HAL and HEAD metrics were $\geq 51.6 \mathrm{~mm}$ and $119.8 \mathrm{~mm}$, respectively. Multiple regression analysis indicated HAL and HEAD metrics were best of 12 morphometrics as indicators of sex $(P<0.04)$. Factorial ANOVAs showed no effect of age class and age class-by-sex interaction on dependent variables HAL and HEAD $(P>0.05)$. Sex assignments by plotting HAL and HEAD metrics of known-sex eagles relative to bivariate normal probability distribution (BNPD) percentile curves were $100 \%$ correct. Discriminate score (DS) derived from discriminate function analysis (DFA) incorporating HAL and HEAD metrics classified our sample eagles with $100 \%$ accuracy. Confirmatory analyses were $100 \%$ accurate. We also evaluated Bortolotti's (1984, Journal of Field Ornithology 55:54-66) methods of sex assignment using eagles we captured: culmen length (CL) and HAL correctly identified $89 \%$ of our known-sex eagles. Six of seven $(86 \%)$ incorrect designations using his ageclass dependent models were males classified as females, likely due to the variable effects of overgrown CLs or shrinkage in the museum specimens Bortolotti used. We propose using empirical data-driven BNPD plots first and then DS models if needed to assign sex to Golden Eagles $>3.5$ mo old in the field. Magnitude of the species' sexual dimorphism may mask clinal differences in intrasex HAL and HEAD metrics throughout the species' latitudinal range and these metrics may be accurate indicators of sex, regardless of age or region of origin in western North America.
\end{abstract}

KEY Words: Golden Eagle, Aquila chrysaetos; hallux claw; head length; morphometrics; sex assignment.

\section{DETERMINACIÓN SEXUAL MORFOMÉTRICA DE INDIVIDUOS NORTEAMERICANOS DE AQUILA CHRYSAETOS CANADIENSIS}

RESUmen.-Realizamos hasta 20 mediciones de 79 individuos capturados de Aquila chrysaetos canadiensis para evaluar las mejores medidas para una determinación sexual morfométrica no invasiva. La confirmación del sexo se realizó luego de la liberación, para 43 machos y 36 hembras de A. c. canadiensis: 60 por análisis de ADN y 19 por la posición durante la copulación. Las águilas con plumaje adulto compusieron el $57 \%$ de las águilas de sexo confirmado. Todas las medias morfométricas de los machos y las hembras difirieron $(P<0.01)$, pero la mayoría $(n=10)$ de los rangos métricos se solaparon $>10 \%$ entre los sexos. No hubo solapamiento entre los sexos para las medidas de la garra del hálux (HAL) y del largo de la cabeza (CABEZA), independientemente de la clase de edad. Todas las medidas de HAL y CABEZA de los machos fueron $\leq 51.7 \mathrm{~mm}$ y $119.5 \mathrm{~mm}$, respectivamente. Todas las medidas de HAL y CABEZA de las hembras fueron $\geq 51.6 \mathrm{~mm}$ y $119.8 \mathrm{~mm}$, respectivamente. Los análisis de regresión múltiple indicaron que de entre 12 medidas morfométricas, las medidas de HAL y CABEZA fueron los mejores indicadores de sexo $(P<$ 0.04). ANAVAS factoriales no evidenciaron ningún efecto de la interacción de clase de edad y clase de edad por sexo en las variables dependientes de HAL y CABEZA $(P>0.05)$. La asignación del sexo mediante el

\footnotetext{
${ }^{1}$ Email address: ubijt@montana.edu
} 
trazado de las medidas de HAL y CABEZA de águilas cuyo sexo era conocido relativo a las curvas percentiles de distribución de probabilidad normal bivariada (DPNB) fue $100 \%$ correcta. La puntuación discriminativa (PD) derivada del análisis de función discriminante (AFD) que incorpora las medidas de HAL y CABEZA clasificó a nuestra muestra de águilas con una precisión del 100\%. Los análisis confirmatorios fueron 100\% precisos. También evaluamos los métodos de Bortolotti (1984, Journal of Field Ornithology 55:54-66) para la asignación de los sexos usando a las águilas que capturamos: largo del culmen (LC) y HAL identificaron correctamente al $89 \%$ de nuestras águilas de sexo conocido. Seis de siete $(86 \%)$ designaciones incorrectas usando estos modelos dependientes de clase de edad fueron machos clasificados como hembras, probablemente debido al efecto variable de sobre crecimiento del LC o a un acortamiento en los especímenes de museo que Bortolotti usó. Proponemos usar primero los datos empíricos derivados del trazado de DPNB y luego modelos de PD si es necesario para asignar el sexo en el campo a individuos de A. c. canadiensis $>3.5$ meses de edad. La magnitud del dimorfismo sexual de la especie puede enmascarar diferencias progresivas en las medidas de HAL y CABEZA de un sexo a lo largo del rango latitudinal de la especie, y estas medidas pueden ser indicadores precisos del sexo, independientemente de la edad o la región de origen en el oeste de América del Norte.

[Traducción del equipo editorial]

North American Golden Eagles (Aquila chrysaetos canadensis) are sexually monomorphic in plumage but sexually dimorphic in size (Bent 1937, Brown and Amadon 1968, Palmer 1988, Watson 1997). Prior to DNA analysis of tissue samples (Ellegren 1996, Griffiths et al. 1998), distinguishing the sex of live Golden Eagles was primarily by morphometric separation. Bortolotti (1984) developed methods for sex assignment of North American Golden Eagles using morphometrics obtained from study skins of various tenures in museums. Edwards and Kochert (1986) related foot pad (sometimes called "toe pad") measurement and body mass to sex of dead male and female Golden Eagles sexed by necropsy. However, study skins or carcasses may shrink or otherwise not always be representative of live birds and applying these techniques to live eagles may be inaccurate. Further, body mass of live eagles may vary more than $10 \%$ based on physiological condition and expanding toes of live eagles, especially adults with clenched feet, in order to make the foot pad measurement, is often difficult and sometimes impossible without injury or excessive investment of time. Edwards and Kochert (1986) recommended that measurements of skeletal structures may be more appropriate for sex assignment than body mass or foot pad measurements.

Although definitive sexing criteria based on DNA have been developed for other Aquila species (e.g., Balbontín et al. 2001), none have been developed for North American Golden Eagles. Polymorphic DNA analysis of blood or feather samples is virtually $100 \%$ accurate and the only method for definitive assignment of sex in birds (Ellegren 1996, Griffiths et al. 1998, Naim et al. 2011) other than witnessing egg-laying or position of marked eagles during copulation. However, assigning the sex of eagles while in hand is often desirable, and preferable to waiting for laboratory analysis or direct observations for confirmation. Here, we present a noninvasive technique for assigning sex using measurements easily obtained for live Golden Eagles >3.5 mo old. We also tested Bortolotti's (1984) method for accuracy on known-sex eagles, but did not test Edwards' and Kochert's (1986) method because we did not measure foot pads.

\section{Methods}

Golden Eagles were captured during all seasons in New Mexico, Colorado, Wyoming, and Montana between 1980 and 2011. Approximately 65\% of the eagles were captured by Coda net launcher (Harmata 2011) with and without live lure Golden Eagles, 32\% by the "Lockhart Method" (padded leg-hold traps: Miner 1975) with and without live lure Golden Eagles, $2 \%$ by hand capture of gorged individuals (e.g., see accounts in Ellis [in press]), and $1 \%$ by noosed jackrabbit (Lepus spp.) carcass (Watson 1985). All were wild and released after marking/sampling. Only eagles captured at least 1 mo post-fledging and with flight feathers fully developed were used in our analyses. We aged eagles based on tail feather coloration associated with plumage classes (Humphrey and Parkes 1959; Table 1 in Bloom and Clark 2001, Ellis 2004). Age classes were juvenile, immature (Basic I and II plumage), subadult (Basic III plumage), and adult. We classified eagles that had no more than one rectrix with subadult characteristics (i.e., white base or streaking) as adult because breeding eagles occasionally display at least one subadult rectrix (Steenhof et al. 1984, A. Harmata unpubl. data). Others 
Table 1. Morphometrics obtained from Golden Eagles live captured in the western Continental United States.

\begin{tabular}{|c|c|c|c|c|}
\hline $\begin{array}{c}\text { TyPE OF } \\
\text { MEASUREMENT }\end{array}$ & MORPHOMETRIC & DESIGNATOR & METHOD & RELIABILITY $^{1}$ \\
\hline \multirow[t]{7}{*}{ Hard } & Tarsal width, AP & TWAP & $\begin{array}{l}\text { Taken at narrowest point on right tibiotarsus } \\
\text { anterio-posteriorily }\end{array}$ & $98.8 \%$ \\
\hline & Tarsal width, lateral & TWLAT & $\begin{array}{l}\text { Taken at narrowest point on right tibiotarsus, } \\
\text { laterally }\end{array}$ & $98.3 \%$ \\
\hline & Culmen length & CL & $\begin{array}{l}\text { Chord of upper mandible from medial distal } \\
\text { cere to tip }\end{array}$ & $99.5 \%$ \\
\hline & Bill depth & $\mathrm{BD}$ & $\begin{array}{l}\text { Depth of closed beak from medial distal cere } \\
\text { to ventral lower mandible }\end{array}$ & $99.4 \%$ \\
\hline & Hallux claw & HAL & Chord of right hallux talon & $99.4 \%$ \\
\hline & Head length & HEAD & $\begin{array}{l}\text { Medial prominence at supraoccipital and } \\
\text { parietal junction to distal extent of upper } \\
\text { mandible, center line of skull }\end{array}$ & $99.4 \%$ \\
\hline & Ulna & ULNA & Right ulna, measured ventrally & $99.8 \%$ \\
\hline \multirow[t]{5}{*}{ Soft } & Wing chord & WC & Chord of right wing, wrist to tip of longest primary & \\
\hline & Flat wing & FW & As in WC, but longest primary flattened & \\
\hline & Wingspan & WS & $\begin{array}{l}\text { 2X extended wing distance, tip of longest } \\
\text { flattened primary to sternum }\end{array}$ & \\
\hline & Tail length & TL & Center rectrix, distal tip to insertion & \\
\hline & Body mass & MASS & $50-\mathrm{g}$ increments adjusted for crop contents (see text) & \\
\hline
\end{tabular}

1 Average range of multiple measures/sample mean; see text.

with $>1$ subadult rectrix that were confirmed as breeders within 3 mo after radio-tagging and release were also classified as adult. We eventually combined juvenile and immature age classes into one immature category and combined subadult and adult age classes into one adult category due to sample size constraints (only thee subadult males).

We obtained up to 12 morphometrics during banding, blood sampling, or auxiliary marking of captured Golden Eagles (Table 1). Measurements were made with mechanical or digital calipers, meter stick or carpenter's rule, seamstress tape, and Pesola scale. Crop contents were estimated in proportions $(p)$ of full crop from 0 to 1.0 in 0.1 increments. Mass of a full crop was estimated by weighing eagles $(n=4)$ with empty crops, force-feeding them until full and reweighing. Mean full crop mass was $567 \mathrm{~g}$ (SD = 7.23). Body mass was calculated by subtracting $\left(p^{*} 567\right)$ from scale value. Measurements were categorized as "hard" (involving mostly skeletal structures) and "soft" (involving feathers and body mass).

Measurements were consistently but not always obtained by the same two individuals but reproducibility was not evaluated. We took two to three measurements of hard variables on some randomly selected individuals to evaluate reliability of our measurements. We evaluated percent reliability by $\left[\left(\bar{X} r_{x} / \bar{X}_{N x}\right)\right]^{*} 100$, where $\bar{X} r_{x}=$ mean of the ranges of multiple readings of a morphometric $x$ for eagles with multiple measurements and $\bar{X}_{N x}=$ mean of morphometric $x$ for the entire sample.

Up to $6 \mathrm{ml}$ of blood were obtained from eagles, mostly for contaminant analysis (e.g., Harmata and Restani 1995, 2013), and a portion of blood samples was selected a posteriori for DNA analysis of sex. Blood was withdrawn from purple top (EDTA anticoagulant) vacutainers using pipettes and deposited on commercial blood spot cards, dried, and shipped to respective laboratories. Some eagles were talon-clipped (outside left or right) to collect a drop of blood on blood spot cards for DNA analysis. DNA testing was completed at three commercial laboratories (WilTell Labs, Jefferson, Oregon; SFO Medical, Santa Clara, California; and Avian Biotech International, Tallahassee, Florida).

We tested Bortolloti's (1984) method of sex determination with our known-sex eagles. We combined our juvenile and immature age classes to represent his immature age class and combined our subadult and adult age classes to represent his adult/subadult age class and applied his respective predictive models. 
Soft metrics involving feather length and body mass (Table 1) were eliminated from analysis to minimize the effect of age class. Differences in morphology among age classes of raptors typically involve feathers (Mueller et al. 1976, 1979, Bortolotti 1984, Pitzer et al. 2008) and body mass of live eagles may vary more than $10 \%$ based on physiological condition. We eliminated hard morphometric variables that were not significantly related to confirmed sex by Generalized Multiple Regression Analysis (MRA). Distributions of significant morphometric variables for confirmed males and females were considered normal if skewness and kurtosis were between \pm 2.0 and outliers discarded. From the subsets of known male and known female, we randomly withdrew three of each sex for later confirmatory analysis.

We applied two analytical procedures. First, we employed an empirical procedure that treated two variables selected by regression analysis jointly in a Bivariate Normal Probability Density (BNPD) distribution process that systematically accounted for the correlation between the two variables (Johnson and Wichern 2007). We plotted the data and constructed percentile curves based on three-dimensional BNPD distributions. Data for each sex were input into the bivariate normal density function. Calculations were performed in Microsoft Excel ${ }^{\mathrm{TM}}$ using built-in function routines in which for each sex distribution, $x$ was the most significant variable (lowest $P$-value) determined by MRA $\left(\mathrm{V}_{1}\right) ; y=$ the variable with next lowest significant $P$-value determined by MRA $\left(\mathrm{V}_{2}\right) ; \mu_{1}=\bar{X} \mathrm{~V}_{1}, \mu_{2}=\bar{X} \mathrm{~V}_{2}, \sigma_{1}=$ Standard Deviation $(\mathrm{SD})\left(\mathrm{V}_{1}\right), \sigma_{2}=\mathrm{SD}\left(\mathrm{V}_{2}\right)$ and $\rho=$ correlation coefficient of $\mathrm{V}_{1}: \mathrm{V}_{2}$. Results were imported into Maple 12 Software (Maplesoft 2008) for production of BNPD curve plots.

Next, we performed a stepwise Discriminate Function Analysis (DFA) incorporating significant morphometric variables identified by regression analysis $\left(\mathrm{V}_{1}, \mathrm{~V}_{2}\right)$ in STATISTICA v6.1 (StatSoft 2003). DFA produced a Discriminate Score (DS) function used for assigning sex. DFA results were verified using data from eagles of confirmed sex not included in original DFA. We further validated DFA results by employing a "leave-one-out classification" (SPSS 2007), sequentially removing one eagle from data set, running the DFA with remaining eagles and confirming sex of the eagle left out.

We calculated $V_{2}$ for specific values of $V_{1}$ and DS in the discriminate function and constructed a contour plot consisting of Level Curves corresponding to several DS values (Stewart 2012). The probability for each Level Curve on the contour plot was calculated by SPSS (2007).

\section{RESULTS}

We confirmed sex for 43 male and 36 female Golden Eagles; sex was determined using DNA analysis for 60 eagles and position during copulation for 19 radio-tagged eagles. Eagles in adult plumage made up 57\% of eagles of confirmed sex. Multiple measurements on individual birds of hard variables revealed maximum range of $1.8 \%$ among measurements (Table 1). Number of measurements (Table 2) taken among eagles varied and 12 eagles were eliminated due to missing data. One male with an exceptionally large head length (HEAD) of $124.2 \mathrm{~mm}$ and one female with an exceptionally small hallux claw (HAL) of $<45.9 \mathrm{~mm}$ (presumed recording errors) and one small male with a HEAD of $114.7 \mathrm{~mm}$ and HAL of $43.8 \mathrm{~mm}$ were identified as outliers and discarded from analyses. Removal of outliers and withdrawals left $n=59$ for in-depth analysis.

Only bill depth (BD) metric distribution violated normality for both sexes. Means of all male and female Golden Eagle morphometrics differed $(P<$ $0.01)$ but ranges of most measurements, including culmen length (CL) used by Bortolotti (1984), overlapped $>10 \%$ (Table 2). We found no overlap between the sexes in HAL and HEAD metrics. For our entire sample of known-sex eagles, maximum HAL and HEAD for males $(n=31 / 42)$ did not exceed $51.7 \mathrm{~mm}$ and $119.4 \mathrm{~mm}$, respectively. For females, minimum HAL and HEAD $(n=31 / 35)$ was not less than $51.7 \mathrm{~mm}$ and $119.9 \mathrm{~mm}$, respectively.

Applying both of Bortolotti's (1984) age-class-dependent models of sex assignment using CL and HAL, we correctly identified the sex of $89 \%$ of our known-sex Golden Eagles that permitted comparison $(n=66)$. In our immature age class, 26 of 29 $(90 \%)$ known-sex eagles were correctly identified. In our adult age class, 33 of $37(89 \%)$ known-sex eagles were correctly identified. All three incorrect classifications in the immature age class were males classified as females. Three of four $(75 \%)$ incorrect classifications in the adult age class were males classified as females.

Multiple Regression Analysis identified HAL $\left(t_{34}=-2.408, P=0.022\right)$ and HEAD $\left(t_{34}=-2.199\right.$, $P=0.035)$ as significant predictors of sex $\left(F_{9,34}=\right.$ 26.808, $\left.P<0.000, R^{2}=0.876\right)$. No other independent variables were significant $(P>0.05)$. 
Table 2. Sample statistics for 12 morphometrics of known-sex Golden Eagles $(n=79)$ captured in the western continental United States. All means were different between the sexes $(P<0.01)$.

\begin{tabular}{|c|c|c|c|c|c|c|c|c|c|c|}
\hline \multirow{2}{*}{$\begin{array}{c}\text { TyPE OF } \\
\text { MEASUREMENT }\end{array}$} & \multirow[b]{2}{*}{ MEtRIC } & \multicolumn{4}{|c|}{$\mathrm{O}^{\prime}$} & \multicolumn{4}{|c|}{ Q } & \multirow{2}{*}{$\begin{array}{c}\% \text { Q: } O^{\prime} \\
\text { OVERLAP }\end{array}$} \\
\hline & & $n^{\mathrm{a}}$ & MEAN & $d$ & MAX & $n^{\mathrm{a}}$ & MEAN & $d$ & MIN & \\
\hline \multirow[t]{7}{*}{ Hard } & TWAP (mm) & 41 & 15.4 & 0.969 & 17.9 & 33 & 17.8 & 1.052 & 15.0 & 0.48 \\
\hline & TWLAT (mm) & 43 & 13.9 & 0.929 & 16.5 & 34 & 16.1 & 1.138 & 14.0 & 0.43 \\
\hline & $\mathrm{CL}(\mathrm{mm})$ & 43 & 42.6 & 1.856 & 47.5 & 35 & 47.3 & 2.362 & 42.4 & 0.36 \\
\hline & $\mathrm{BD}(\mathrm{mm})$ & 41 & 28.2 & 0.847 & 31.3 & 34 & 30.1 & 0.825 & 28.2 & 0.55 \\
\hline & $\mathrm{HEAD}(\mathrm{mm})$ & 43 & 115.7 & 2.011 & 119.4 & 35 & 124.4 & 2.603 & 119.9 & -0.03 \\
\hline & $\mathrm{HAL}(\mathrm{mm})$ & 35 & 49.4 & 1.621 & 51.7 & 31 & 55.5 & 2.016 & 51.7 & 0 \\
\hline & ULNA $(\mathrm{mm})$ & 27 & 227.6 & 5.603 & 240 & 30 & 246 & 8.050 & 232 & 0.11 \\
\hline \multirow[t]{5}{*}{ Soft } & WC $(\mathrm{cm})$ & 22 & 58.9 & 1.514 & 62.2 & 14 & 62.6 & 1.847 & 59.1 & 0.33 \\
\hline & $\mathrm{FW}(\mathrm{cm})$ & 21 & 60.0 & 1.526 & 63.5 & 14 & 64.2 & 1.524 & 61.6 & 0.21 \\
\hline & $\mathrm{TL}(\mathrm{cm})$ & 21 & 32.2 & 1.294 & 34.9 & 14 & 34.8 & 1.641 & 33.0 & 0.23 \\
\hline & WS $(\mathrm{cm})$ & 20 & 193.4 & 8.498 & 205.7 & 13 & 207.6 & 6.347 & 195.6 & 0.27 \\
\hline & MASS (gm) & 41 & 3749 & 364.65 & 4936 & 35 & 4822 & 575.49 & 4039 & 0.27 \\
\hline
\end{tabular}

a Difference in sample sizes were due to alacrity required for release before dark, varied objectives, competence of handlers, and forgetfulness.

b $\left(\sigma^{\prime} \max -\wp \min \right) /\left(\wp \max -O^{\prime \prime} \min \right)$.

Factorial ANOVA indicated there were large main effects of sex on HAL $\left(F_{1,55}=171.53, P<0.01\right)$ and $\operatorname{HEAD}\left(F_{1,55}=148.48, P<0.01\right)$ metrics. However, we found no effect of age class (adult: immature) on either HAL $\left(F_{1,55}=0.051, P=0.82\right)$ or $\operatorname{HEAD}\left(F_{1,55}\right.$ $=0.51, P=0.07)$ metrics. There was also no evidence of sex- and age-class interaction with HAL or HEAD metrics $\left(F_{1,55}<0.285, P>0.60\right)$. Thus, adult and immature age classes were combined in further analyses.

HAL and HEAD descriptive statistics (Table 3) produced distinct BNPD curves for males and females, derived from empirical data (Fig. 1). Variability of female morphometrics was greater than that of males; no males had coordinates within the Area of Uncertainty while $17 \%(n=35)$ of females

Table 3. Descriptive statistics of hallux claw (HAL) and head length (HEAD) metrics of confirmed sex Golden Eagles $(n=59)$ of all age classes $(>3.5$ mo old $)$ captured in the western continental United States and used in BNPD analysis. Analysis indicated no effect of age class on measurements (see text).

\begin{tabular}{llrcc}
\hline SEX $(n)$ & METRIC & MEAN & SD & $\mathrm{r}^{\mathrm{a}}$ \\
\hline Male (31) & HAL & 49.7 & 2.012 & 0.217 \\
& HEAD & 115.9 & 1.131 & \\
Female (28) & HAL & 55.6 & 1.946 & 0.202 \\
& HEAD & 124.5 & 2.734 & \\
\hline
\end{tabular}

a Correlation coefficient of HAL and HEAD. did (Fig. 1). Range of uncertainty was slightly less for HEAD (12.6\%) than HAL metric (13.6\%) and HEAD and HAL metrics were loosely correlated (Table 3). Eagles encountered in the wild population may be sexed with $95 \%$ certainty if HAL and HEAD coordinates fall above (females) or below (males) their respective BNPD percentile curves (Fig. 1). Further analysis is indicated if coordinates fall within the Area of Uncertainty.

Stepwise DFA of HAL and HEAD significantly discriminated between the sexes (Wilks' $\lambda=0.146$, $\left.\chi^{2} 2,59=107.862, P<0.01\right)$, regardless of age class with $85.4 \%$ of variability explained. Both metrics had $99.4 \%$ reliability of measurement as indicated by multiple measures (Table 1). HAL entered DFA first as the most discriminating variable (Exact $F_{1,57}$ $=214.5, P<0.001)$ followed by HEAD (Exact $F_{2,56}$ $=164.0, P<0.001)$. DFA produced the function DS $=-54.5+0.257 *(\mathrm{HEAD})+0.452 *(\mathrm{HAL})$. Classification of all known-sex eagles (excluding outliers) by DS $(n=66)$ was $100 \%$ correct. Thus, for determining sex of Golden Eagles, those with DS values $<0$ are considered males and those with DS values $>0$ are considered females. Validation of DFA by leave-one-out procedure was $100 \%$ correct as was DS classification of six known-sex eagles not included in any previous analysis.

Contour plot of DS function of HAL and HEAD metrics produced a flat plane Level Curve from which probabilities from $50 \%$ to $>98 \%$ for females and $>99 \%$ for males were calculated. The scale of 


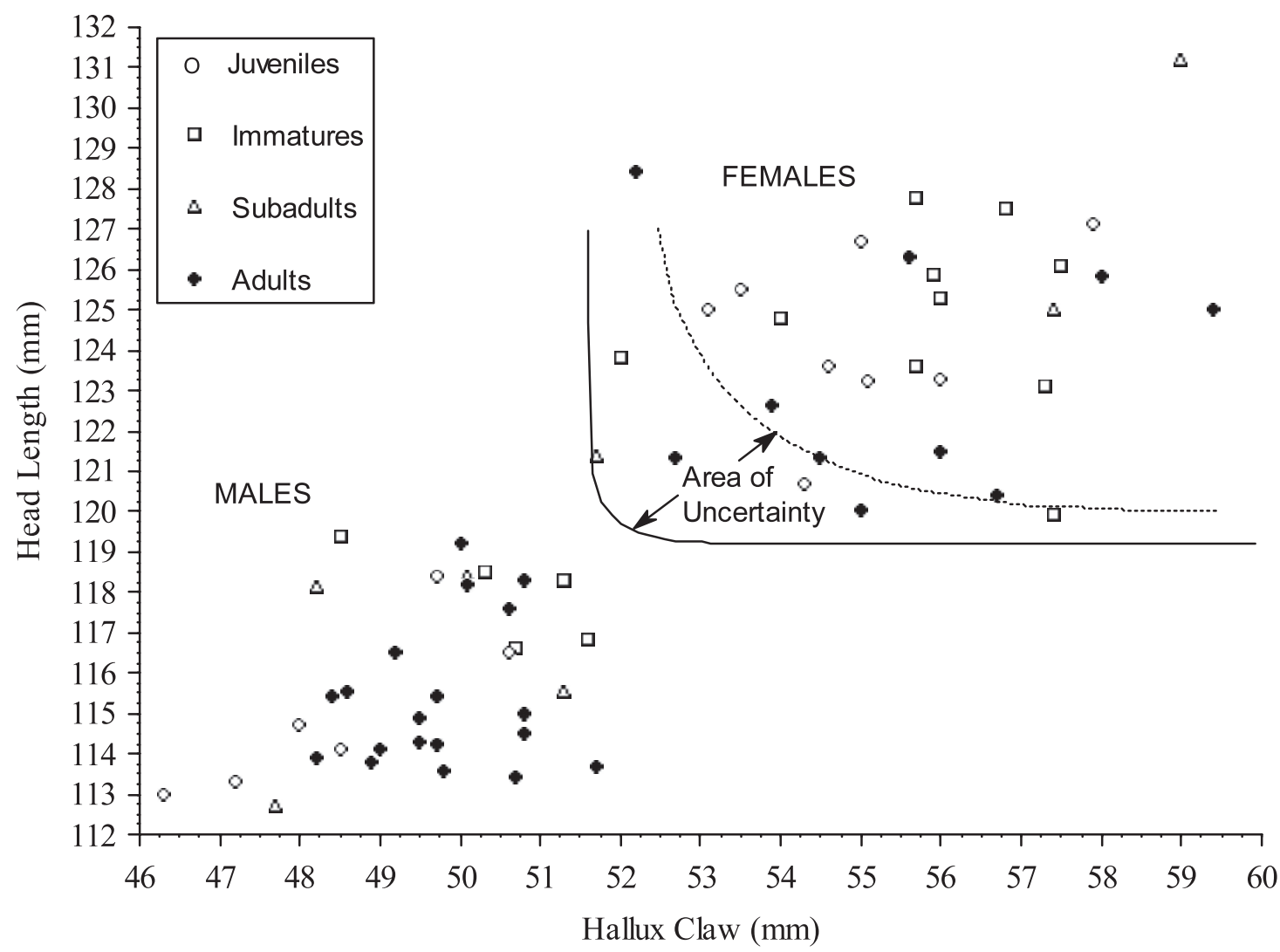

Figure 1. Bivariate Normal Probability Density (BNPD) distributions (curves) and plots of hallux claw and head length of 66 Golden Eagles of confirmed sex captured alive in the western continental United States. Lower left curve (solid line) is $95^{\text {th }}$ percentile of all males; upper right curve (dotted line) is $5^{\text {th }}$ percentile of all females. All eagles represented above and right of the solid line are females; all below and left of the solid line are males.

probabilities is essentially linear and may be approximated when interpolating between contour lines (Fig. 2).

\section{DISCUSSION}

Accuracy of the Bortolotti Method. Bortolotti's (1984) method appeared slightly less accurate for classifying sex of large males correctly. The Bortollotti (1984) models relied heavily on CL to determine sex. However, we found a $36 \%$ overlap in this metric between the sexes (Table 2). Natural hyperplasia of the rhamphotheca is common in captive eagles and was evident in some wild eagles (A. Harmata unpubl data). Heavy reliance on CL for classification would tend to classify smaller birds with overgrown culmens as being larger. Additionally, soft tissue on specimens of lengthy museum tenure may be subject to desiccation and shrinking. If a specimen's toe and possibly cere tissue shrank appreciably, HAL and CL measurements (used by Bortolotti (1984)) would be larger than if it were alive (G. Bortolotti unpubl. data), thus also promoting female classification rather than male.

Bortolotti (1984) suggested that HAL also varied with age, but $43 \%$ of the eagles in our study were not full adults. HAL and HEAD lengths of our known-sex eagles did not overlap regardless of age class, suggesting both structures may be relatively fixed once eagles fledge and thus may be good indicators of sex, regardless of age.

Sex Assignment Procedure in the Field. We believe that the quickest method to sex Golden Eagles in the field would be use of BNDP curves. Most field researchers use data sheets to record biometric information. Adding Figure 1 to a data sheet and plotting subjects' HEAD and HAL metrics would be a 


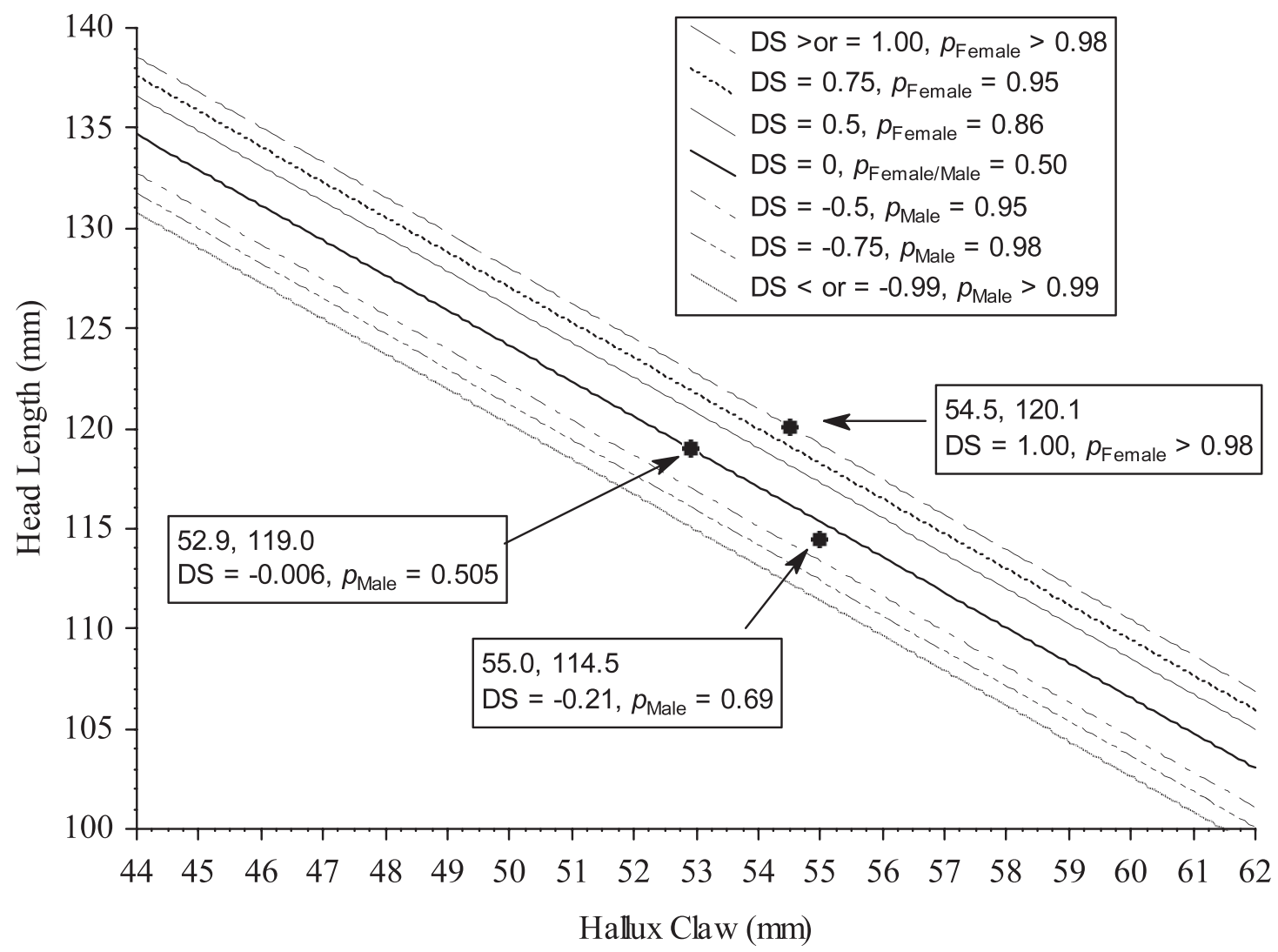

Figure 2. Probabilities of correct classification derived from contour plot of Discriminate Score (DS) functions of known male and female Golden Eagle metrics. Example plots of two male and one female Golden Eagles' hallux claw and head length metrics (dots) and their Discriminate Scores are displayed with associated probabilities $(p)$ of occurrence.

simple task. Golden Eagles with HAL (x) and HEAD (y) coordinates that fall to the right and above the 5\% female BNPD curve (dotted line, Fig. 1) or left and below the 95\% male BNPD curve (solid line, Fig. 1), especially those close to the centers of dispersion (females $=$ HAL $\sim 54.5$, HEAD $\sim 124.0$; males $=$ HAL 49.0, HEAD 116.0) may be sexed with a high degree of probability ( $\geq 95 \%)$ and no other attention may be needed. Sex of Golden Eagles with HAL (x) and HEAD (y) coordinates that fall within the Area of Uncertainty (between curves, Fig. 1) could be confirmed by DS (DS $=-54.5+0.257 *(\mathrm{HEAD})+$ $0.452 *(\mathrm{HAL}))$ and probability of occurrence determined by plotting coordinates on Figure 2 . These methods may be used with confidence for sexing Golden Eagles at least 3.5 mo old in the field, regardless of age class and at least within the Rocky Mountain states.

Applying both empirical data-driven (BNDP) and predictive (DFA) models to sexing Golden Eagles in the field will enhance probability of correct classification. BNPD plots (outside the Area of Uncertainty) of HAL and HEAD metrics of Golden Eagles produce at least a $95 \%$ probability of correct classification. Used with DS, probability is increased to at least $99 \%\left[p=\left(1-0.05^{2}\right) * 100 \%=99.75 \%\right]$. If a BNPD plot falls in the Area of Uncertainty, DFA assignment is necessary. However, if methods disagree, i.e., assign different sexes, sex assignment by other means (e.g., DNA, copulation position, egg laying) may be required.

Range of Applicability to Western Golden Eagle Populations. Bergmann's Ecogeographical Rule (Bergmann 1847) has been shown to apply to birds throughout the world, including eagles (Ashton 2002, Shephard et al. 2004). Regional size differences have been noted in raptors (Smith et al. 1990, Hoffman et al. 1990, Fitzpatrick and Dunk 1999, Pearlstine and Thompson 2004, Pitzer et al. 2008) but 
specifics applicable to A. c. canadensis are lacking. Eagles used in our study were captured from northern New Mexico ( $35^{\circ} \mathrm{N}$ latitude) to near the Canadian border in Montana $\left(49^{\circ} \mathrm{N}\right.$ latitude) and included resident breeders and at least two migrants banded as nestlings in Alaska $\left(63^{\circ} \mathrm{N}\right.$ latitude; McIntyre 2012). Our sample likely included several more birds from northern Canada and Alaska as many were captured during migration in an area known as a Golden Eagle vernal migration corridor (Harmata and Restani 1995).

HAL and HEAD of known-sex eagles in our study did not overlap, regardless of age class, suggesting that if Golden Eagles originating in northern latitudes are larger, size differences probably are manifest in structures with large overlaps between sexes (i.e., wing, tail, body mass, and tarsus; Table 3 ) rather than HAL and HEAD. If clinal differences in HAL and HEAD also exist, they may be masked by the magnitude of the species' sexual dimorphism, i.e., swamped by larger sex differences and thus may be representative of sex throughout the species' latitudinal range, at least through the Rocky Mountain corridor in North America.

\section{ACKNOWLEDGMENTS}

Funding and support was provided by a variety of state and federal public and private land management and conservation agencies and institutions in four western states over two-plus decades. We are indebted to a multitude of enlightened stockmen, ranchers, farmers and other private landowners and managers who extended interest, access, and friendship essential for obtaining sample eagles for this study. M. Restani participated in capture, banding, and measuring many eagles. D. Stahlecker permitted use of morphometrics and DNA results of eagles we captured for his studies. J. Balbontín, G. Bortolotti, M. Ferrer, and three anonymous reviewers provided valuable input and criticism of earlier drafts of this manuscript. D. Russow provided assistance with application of Maple software.

\section{Literature Cited}

Ashton, K.G. 2002. Patterns of within-species body size variation of birds: strong evidence for Bergmann's rule. Global Ecology and Biogeography 11:505-523.

Balbontín, J., M. Ferrer, AND E. Casado. 2001. Sex determination in Booted Eagles (Hieraaetus pennatus) using molecular procedures and discriminant function analysis. Journal of Raptor Research 35:20-23.

BENT, A.C. 1937. Life histories of North American birds of prey, Part One. Smithsonian Institution. United States National Museum Bulletin 167. Dover Publications, Inc., New York, NY U.S.A.

BergmanN, C. 1847. Über die Verhältnisse der Wärmeökonomie der Thiere zu ihrer Grösse. Göttinger Studien 3:595-708.
BloOM, P.H. AND W.S. Clark. 2001. Molt and sequence of plumages of Golden Eagles and a technique for inhand ageing. North American Bird Bander 26:97-116.

Bortolotti, G.R. 1984. Age and sex size variation in Golden Eagles. Journal of Field Ornithology 55:54-66.

BROwn, L.H. AND D. AMADON. 1968. Eagles, hawks, and falcons of the world. McGraw-Hill, New York, NY U.S.A.

EDWARDS, T.C., JR. AND M.N. KoChERT. 1986. Use of body weight and length of footpad as predictors of sex in Golden Eagles. Journal of Field Ornithology 57:317-319.

Ellegren, H. 1996. First gene on the avian W chromosome (CHD) provides a tag for universal sexing of non-ratite birds. Proceedings of the Royal Society of London 263:16351644.

ELLIS, D.H. 2004. Mottling in the plumage of juvenile Golden Eagles. North American Bird Bander 29:53-58.

. In press. Enter the realm of the Golden Eagle. Hancock House Publishing, Blaine, WA U.S.A.

FitzPATRICK, B.M. AND J.R. Dunk. 1999. Ecogeographic variation in morphology of Red-tailed Hawks in western North America. Journal of Raptor Research 33:305312.

GrifFiths, R., M.C. Double, K. ORR, ANd R.J.G. Dawson. 1998. A DNA test to sex most birds. Molecular Ecology 7:10711075 .

HarmatA, A.R. 2011. Environmental contaminants in tissues of Bald Eagles sampled in southwestern Montana, 2006-2008. Journal of Raptor Research 45:119-135.

- AND M. Restani. 1995. Environmental contaminants and cholinesterase in blood of vernal migrant Bald and Golden eagles in Montana. Intermountain Journal of Science 1:1-15.

— AND 2013. Lead, mercury, selenium and other trace elements in tissues of Golden Eagles from southwestern Montana. Journal of Wildlife Diseases 49:114-124.

Hoffman, S.W., J. Smith, AND J. Gessaman. 1990. Size of fall-migrant accipiters in the Goshute Mountains of Nevada. Journal of Field Ornithology 61:201-211.

Humphrey, P.S. ANd K.C. Parkes. 1959. An approach to the study of molts and plumages. Auk 76:1-31.

JoHnson, R.A. AND D.W. Wichern. 2007. Applied multivariate statistical analysis, Sixth Ed. Pearson Prentice Hall, Upper Saddle River, NJ U.S.A.

MAPLESOFT. 2008. Maple 12 Software. Waterloo Maple Inc., Waterloo, ON Canada.

MCINTYRE, C. 2012. Quantifying sources of mortality and wintering ranges of Golden Eagles from interior Alaska using banding and satellite tracking. Journal of Raptor Research 46:129-134.

MineR, N.R. 1975. Montana Golden Eagle removal and translocation project. Great Plains Wildlife Damage Control Workshop Proceedings 201:155-162.

Mueller, H.C., D.D. Berger, AND G. Allez. 1976. Age and sex variation in the size of goshawks. Bird-Banding 47:310-318.

$\longrightarrow, \longrightarrow$, AND -1979 . Age and sex differences in size of Sharp-shinned Hawks. Bird-Banding 50:34-44. 
NAIM, D.M., S.A.M. Nor, AND M.H. BAHARUdDIN. 2011. Noninvasive sex identification of the White-bellied Sea Eagle (Haliaeetus leucogaster) through genetic analysis of feathers. Genetics and Molecular Research 10:2505-2510.

PALMER, R.S. [ED.]. 1988. Handbook of North American birds, Vol. 5. Yale University Press, New Haven, CT U.S.A.

Pearlstine, E.V. And D.B. Thompson. 2004. Geographic variation in morphology of four species of migratory raptors. Journal of Raptor Research 38:334-342.

Pitzer, S., J. Hull, H.B. Ernest, And A.C. Hull. 2008. Sex determination of three raptor species using morphology and molecular techniques. Journal of Field Ornithology 79:71-79.

Shephard, J.M., C.P. Catterall, and J.M. Hughes. 2004. Discrimination of sex in the White-bellied Sea-eagle, Haliaeetus leucogaster, using genetic and morphometric techniques. Еmu 104:83-87.

Smith, J., S. Hoffman, and J. Gessaman. 1990. Regional size differences among fall-migrant accipiters in North America. Journal of Field Ornithology 61:192-200.
SPSS INC. 2007. SPSS Base 16.0 for Windows. SPSS Inc., Chicago, IL U.S.A.

StatSoft, INC. 2003. STATISTICA (data analysis software system), version 6. www.statsoft.com (last accessed October 2012).

Steenhof, K., M.N. Kochert, And M.Q. Moritsch. 1984. Dispersal and migration of southwestern Idaho raptors. Journal of Field Ornithology 55:357-368.

STEWART, J. 2012. Calculus: early transcendentals, Seventh Ed. Brooks/Cole Cengage Learning, Belmont, CA U.S.A.

WATSON, J.W. 1985. Trapping, marking and radio monitoring Rough-legged Hawks. North American Bird Bander 10:9-10.

Watson, J. 1997. The Golden Eagle. T. and A.D. Poyser, Ltd., London, U.K.

Received 20 April 2012; accepted 24 August 2012 Associate Editor: Vincenzo Penteriani 